\begin{tabular}{|l|l|l|}
\hline \multicolumn{2}{|c|}{ PublisherInfo } \\
\hline \hline PublisherName & $:$ & BioMed Central \\
\hline \hline PublisherLocation & $:$ & London \\
\hline \hline PublisherImprintName & $:$ & BioMed Central \\
\hline \hline
\end{tabular}

\title{
Can we affect outcome following head injury?
}

\begin{tabular}{|l|l|l||}
\hline \multicolumn{2}{|c||}{ ArticleInfo } \\
\hline \hline ArticleID & $:$ & 4105 \\
\hline \hline ArticleDOI & $:$ & $10.1186 /$ ccf-1999-2342 \\
\hline \hline ArticleCitationID & $:$ & 2342 \\
\hline \hline ArticleSequenceNumber & $:$ & 42 \\
\hline \hline ArticleCategory & $:$ & Paper Report \\
\hline \hline ArticleFirstPage & $:$ & 1 \\
\hline \hline ArticleLastPage & $:$ & 3 \\
\hline \hline & & RegistrationDate : 1999-12-1 \\
\hline ArticleHistory & $:$ & OnlineDate \\
\hline \hline ArticleCopyright & $:$ & Current Science Ltd1999-12-1 \\
\hline \hline ArticleGrants & $:$ & \\
\hline \hline ArticleContext & $:$ & 130541111 \\
\hline \hline
\end{tabular}




\section{Keywords}

Cerebral perfusion pressure, intracranial hypertension, jugular venous desaturation, jugular venous oxygen saturation monitoring, secondary ischaemic insults, severe head injury, traumatic brain injury

\section{Comments}

The interesting finding that CBF-targeted protocol could be considered beneficial in the prevention of secondary ischaemic insult. The authors did not suggest a reason for the significant increase in ARDS in this group. The use of a randomised trial here has helped to clarify one aspect of the critical care management of head injured patients, but also emphasises, by the lack of improvement in outcome, that care of such injuries is multifactorial.

\section{Introduction}

Following traumatic brain injury, cerebral autoregulation is impaired and the brain is then susceptible to secondary ischaemic insults, which can increase the severity of neurological damage.As little is understood about the control of cerebral blood flow (CBF), one management option for these patients, is to maintain a higher than normal blood pressure and, therefore, cerebral perfusion pressure (CPP). It is felt that this will maintain an adequate $\mathrm{CBF}$, despite impaired autoregulation.

\section{Aims}

This study aimed to compare two management protocols for head injury. Management was either targeted to intracranial pressure (ICP) or $\mathrm{CBF}$ (as assessed by jugular venous oxygen saturation $\mathrm{SjvO}_{2}$ ).

\section{Methods}


In total, 189 eligible patients were randomised (according to time blocks) on admission to the intensive care unti (ICU) to one of two groups:1) ICP targeted (ICP $<20$, MAP $>70 \mathrm{~mm} \mathrm{Hg}$ );2) CBF targeted (MAP $>90, \mathrm{PaCO}_{2} 4.6 \mathrm{kPa}$ ). All other aspects of care were similar in both groups and guided by experimental protocols. Hyperventilation to $\mathrm{PaCO}_{2}$ of 3.3 to $4 \mathrm{kPa}$ was used to treat intracranial hypertension. The primary outcome studied was the frequency of jugular venous desaturation $\left(\mathrm{SjvO}_{2}<50 \%\right.$ for more than $\left.10 \mathrm{~min}\right)$. Secondary outcomes included refractory intracranial hypertension (ICP $>25 \mathrm{~mm} \mathrm{Hg}$ unresponsive to treatment), 3 and 6 month Glasgow outcome score and disability rating scale (by blinded personnel). Complications such as intracranial hemorrhage, acute respiratory distress syndrome (ARDS) and acute renal failure were also examined.

\section{Results}

The average $\mathrm{SjvO}_{2}$ was slightly higher in the $\mathrm{CBF}$-targeted group (73.2\% vs. $70.8 \%$ in the ICPtargeted group). The frequency of jugular venous desaturation was increased in the ICP-targeted group (50.6\% vs. 30\% in the CBF-targeted group). The risk of cerebral ischaemia was assessed by the authors to be 2.4 fold greater with ICP-targeted protocol. However, there was no difference in neurological outcome.

\section{Discussion}

Secondary ischaemic insults caused by systemic factors can be prevented with a targeted management protocol. However, the benefits of a CBF-targeted protocol may be offset by a five-fold increase in the frequency of ARDS.

\section{References}

1. Robertson CS, Valadka AB, Hannay HJ, Contant CF, Gopinath SP, Cormio M, Uzura M, Grossman RG: Prevention of secondary ischemic insults after severe head injury . Crit Care Med. 1999, 27: 2086-2095 . 